\title{
Optical properties of natural dyes: prospect of application in dye sensitized solar cells (DSSCs) and organic light emitting diodes (OLEDs)
}

\author{
${ }^{1}$ Paudel, P.N., ${ }^{2}$ Pandey, A., ${ }^{1}$ Shrestha, R.R., ${ }^{2}$ Neupane, A., ${ }^{1}$ Lamichhane, P., ${ }^{3}$ Adhikari, R., \\ ${ }^{4}$ Gyawali, R. and ${ }^{1 *}$ Kafle, B.P. \\ ${ }^{1}$ Department of Chemical Science and Engineering, Kathmandu University, Nepal \\ ${ }^{2}$ Department of Biotechnology, Kathmandu University, Nepal \\ ${ }^{3}$ Angstrom Technologies Inc., Kentucky, USA \\ ${ }^{4}$ Department of Pharmacy, Kathmandu University, Nepal
}

\begin{abstract}
Article history:
Received: 27 April 2018

Received in revised form: 8

June 2018

Accepted: 10 June 2018

Available Online: 17 June

2018
\end{abstract}

Keywords:

Natural dye,

Absorbance,

Dye-sensitized solar cell,

OLED

DOI:

https://doi.org/10.26656/fr.2017.2(5).096

\begin{abstract}
Optical properties (absorbance, fluorescence, and transmittance) of the natural dyes extracted from flower, leaf, bark and rhizome of some plant species available in Nepal have been explored, with the prospect of application in dye-sensitized solar cells (DSSCs) and organic light emitting diode (OLED) employing UV-Vis., Fluorescence and FTIR Spectroscopy. The extraction process was carried out using solvents with a varying polarity index of ca. 0 to 10: cyclohexane (CH), dichloromethane (DCM), acetone, ethanol $(\mathrm{EtOH})$, methanol $(\mathrm{MeOH})$ and double distilled water (DDW). The absorbance was found to depend on the nature of solvent used; the dye samples, $A$. vasica Nees (in DDW, acetone, $\mathrm{DCM}$ and $\mathrm{CH}$ ), N. arbor-tristis $\mathrm{L}$ (in $\mathrm{MeOH}$ and $\mathrm{CH}$ ), U. dioica $\mathrm{L}$ (in $\mathrm{EtOH}$, acetone, DCM and cyclohexane), O. wightiana Wall (in acetone and $\mathrm{CH}$ ), A. vulgaris $\mathrm{L}$ (in DCM and cyclohexane), C. coccinea Wall (in DCM), R. anthopogon D.Don (in DCM) and $W$. fruticosa $\mathrm{L}$ (in $\mathrm{CH}$ ), showed good absorbance in the visible-region and blue shift in the absorbance maxima was noticed with increase of the polarity index of solvents. Some plant extracts showed intense fluorescence emission in the visible region, which hints at their prospect of application in the OLED devices.
\end{abstract}

\section{Introduction}

Nepal, with its diverse flora, is a storehouse of economically important plant species which can have high potential applications in drug synthesis, textile dye, and cosmetics. Traditionally many of the plant species such as Acacia nilotica Linn., Alnus glutinosa Linn., Althaea rosea Cav., Curcuma longa Linn., Lawsonia alba Linn. and Woodfordia fruticosa Kurz have been utilized to extract natural dyes (Gokhale et al., 2004) in these regards. Also, as natural dyes are colorants they also have prospects of employing as a light absorber (sensitizer) in DSSC and also as a fluorescence emitter in OLED: In DSSCs, these materials are considered promising for utilizing as a sensitizer instead of less environmentally friendly organo-metallic complexes (e.g., Ruthenium dye). In this connection, some of the dyes used as sensitizer are cyanin, anthocyanin, tannin, chlorophyll, betalains, carotenoids (Gao et al., 2000; Sirimanne et al., 2006; Fernando et al., 2008; Calogero et al., 2010).

The first DSSC, which belong to thin film solar cells, was realized with a chlorophyll sensitized zinc oxide ( $\mathrm{ZnO})$ electrode in 1972 and is considered to be a promising means toward harvesting solar energy in low cost (EIER, 2006). In particular, it comprises a thin film of a compound semiconductor with a wide bandgap (mostly titanium oxide $\left(\mathrm{TiO}_{2}\right)$ or zinc oxide $(\mathrm{ZnO})$ ) on top of which a dye is coated for photosensitization. This kind of photo-cell is also known as the "Grätzelcell", which was originally co-invented in 1988 by Brian O'Regan and Michael Grätzel (O'Regan and Gratzel, 1991; Nazerruddin et al., 1993; Grätzel, 2003). In DSSCs, when a dye molecule is photo-excited, the electron jumps from HOMO to LUMO level of dye. If the LUMO of dye matches with the conduction band of the compound semiconductor electron hops to the later material, reach to load and eventually recombines with the ionized dye molecules with the aid of electrolyte.

With $\mathrm{TiO}_{2}$-based dye-sensitized solar cells, a maximum of $14 \%$ efficiency has been achieved using standard ruthenium polypyridyl complexes as a sensitizer in the laboratory condition (Nazeeruddin et al., 2005; 
Qin and Peng, 2012). Further improvement in photovoltaic properties and durability of these kinds of cells by utilizing an appropriate sensitizer would certainly facilitate widespread utilization of this technology.

There are several studies that employ the natural dyes as a sensitizer (Hao et al., 2006; Chang and Lo, 2010; Susanti et al., 2014) but the downside is that they have low efficiency. This problem can be circumvented by identifying natural dyes which increase the performance efficiency. For example, Susanti et al., 2014, has reported the performance of photo-cells fabricated with $\mathrm{ZnO}$ and tamarillo fruit as a sensitizing dye. Similarly, the extracts from spinach and ipomoea were used as good natural sensitizers for dye sensitized solar cells (Chang et al., 2010). Higher incident photon to current conversion efficiency (IPCE), which is proportional to the absorption coefficient of the dye, over the visible and near IR region of the solar spectrum, is one of the necessary conditions to achieve enhanced solar cells performance. Therefore, this study has focused on identifying the natural dyes which show good absorbance over the visible and near-IR regions.

\section{Materials and methods}

Extracts of natural dye from fifteen plant species (flower, leaf, bark, and rhizome) were obtained with the solvent extraction method using both the polar and nonpolar solvents; double distilled water (DDW), methanol $(\mathrm{MeOH})$, ethanol $(\mathrm{EtOH})$, acetone, dichloromethane (DCM) and cyclohexane (CH). The plant samples collected for extraction of natural dyes were: 1. A. vasica Nees (local name: Asuro, leaf), 2. A. vulgaris L (Titepati, leaves), 3. B. aristata DC (Chutro, bark), 4. M. esculenta Buch Ham (Kaphal, bark), 5. N. grandiflora DC (Jatamarsi, rhizome), 6. U. dioica L (Sisno, leaves), 7. J. humile L (Jaai, flower), 8. R. arborium L. (Laliguras, bark), 9. O. wightiana Wall (Nundhiki, leaves), 10. N. arbor-tristis L (Parijat, flower), 11. C. coccinea Wall (Sano Tusare, bark), 12. A. vasica Nees (Asuro, flower), 13. R. anthopogon D.Don (Sunpati, leaves), 14. B. ceiba $\mathrm{L}$ (simal, flower) and 15. W. fruticosa L (Dhairo, flower).

Methods of extraction and measurements are shown in Figure 1. Dye was extracted from each plant sample (crushed in powder form) by solvent extraction process in various solvents. Then the extract was separated from the residue by filtration. The solvent was removed from dye extract by evaporation at around $50^{\circ} \mathrm{C}$. Then, 0.01 gm of solid extract (residue after removal of solvent) of each dye was re-dissolved in a desired solvent for recording absorbance-, fluorescence- and IR- spectra.
The absorbance and fluorescence of all the dye samples were measured on the Genesis-10 UV-Visible spectrophotometer and F93 Fluoro-Spectrophotometer in the wavelength of $300-900 \mathrm{~nm}$. To identify probable chromophore groups present in a given natural dye, IR spectra were recorded with FT-IR spectroscopy (Shimadzu Corporation, IRPrestige21).

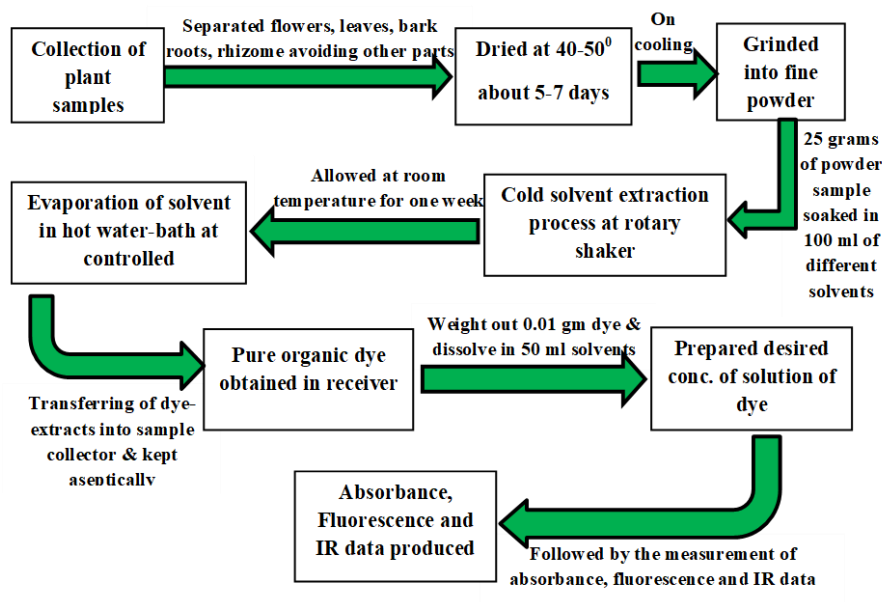

Figure 1. Schematic representation of the methods followed for the extraction of the natural dye and measurement of absorbance, fluorescence and IR spectra.

\section{Results and discussion}

The extracts obtained from a total of 15 plant samples by using cold solvent extraction method were re -dissolved in the same solvent in which they were originally extracted. The solutions were then used for investigation of their optical properties, in particular, absorbance, fluorescence, and transmittance (IR spectroscopy). The observed results are summarized in the following subsections.

\subsection{Absorption of natural dye}

Figure 2 shows UV-Vis absorption spectra as a function of radiation wavelength for all natural dyes. Among all the natural dye samples studied; A. vasica Nees and $M$. esculenta Buch Ham (in DDW), $R$. arborium L. and $N$. arbor-tristis $\mathrm{L}$ (in $\mathrm{MeOH}$ ), $B$. aristata $\mathrm{DC}$ and $U$. dioica $\mathrm{L}$ (in $\mathrm{EtOH}$ ), B. aristata $\mathrm{DC}$, $U$. dioica $\mathrm{L}, J$. humile $\mathrm{L}, R$. arborium L., $O$. wightiana Wall, $C$. coccinea Wall, A. vasica Nees (Flower, in DDW), $R$. anthopogon D.Don and $W$. fruticosa L (in Acetone), A. vasica Nees, A. vulgaris L, $U$. dioica $\mathrm{L}, J$. humile L, $N$. arbor-tristis L, $C$. coccinea Wall and $W$. fruticosa $\mathrm{L}$ (in DCM) and A. vasica Nees, A. vulgaris $\mathrm{L}$, $U$. dioica L, O. wightiana Wall, $N$. arbor-tristis $\mathrm{L}$ and $W$. fruticosa $\mathrm{L}$ (in $\mathrm{CH}$ ), exhibited a broad absorbance peak from wavelength $(\lambda)$ ca. $300 \mathrm{~nm}$ (onset) - ca.500 nm (offset) and another additional sharp peak at $\sim 650 \mathrm{~nm}$ with FWHM of ca. $15 \mathrm{~nm}$. Among all the analyzed samples, $A$. vasica Nees (in DDW), N. arbor-tristis L (in 

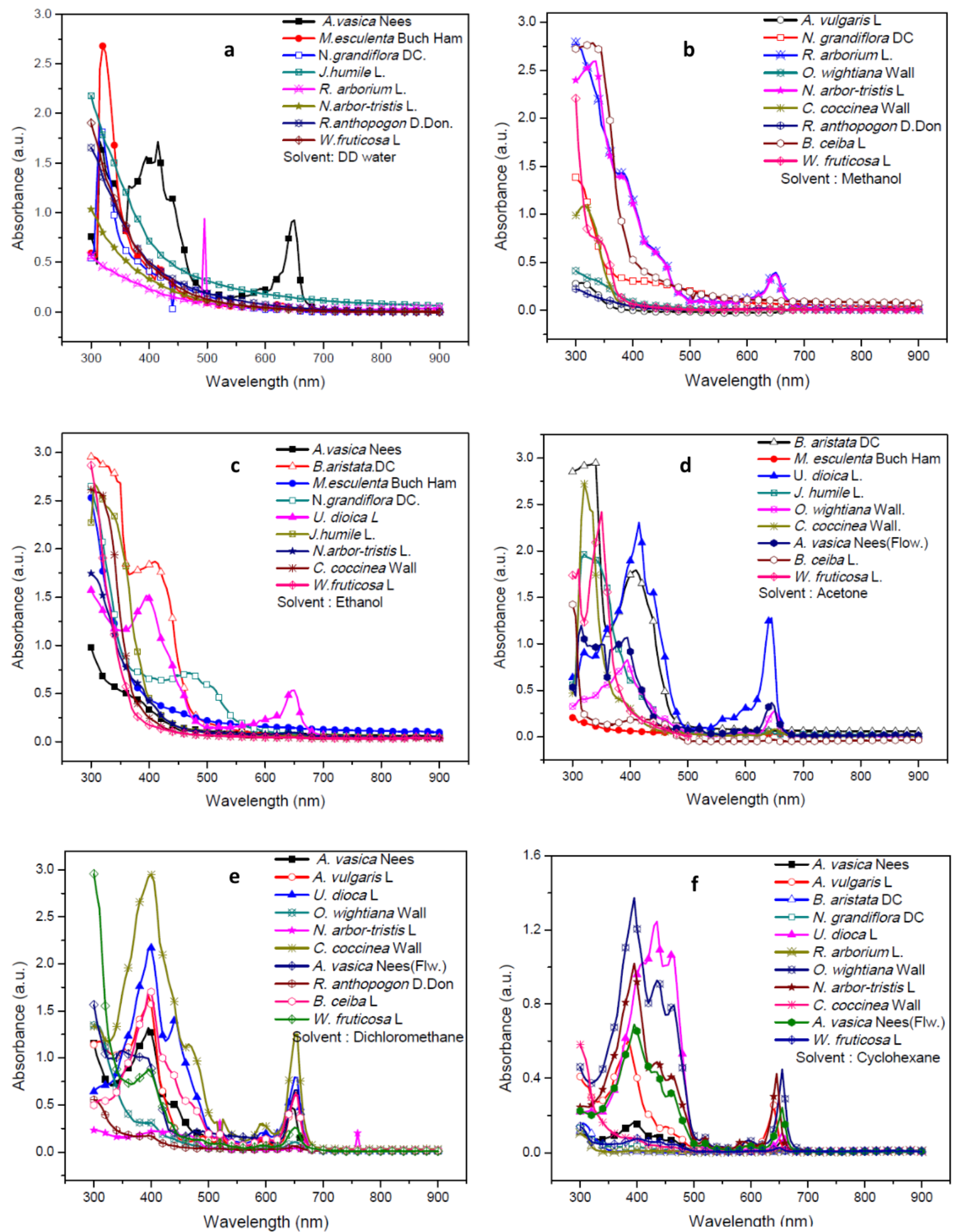

Figure $2(\mathrm{a}-\mathrm{f})$. Absorbance as a function of radiation wavelength for natural dye samples extracted in different solvents 

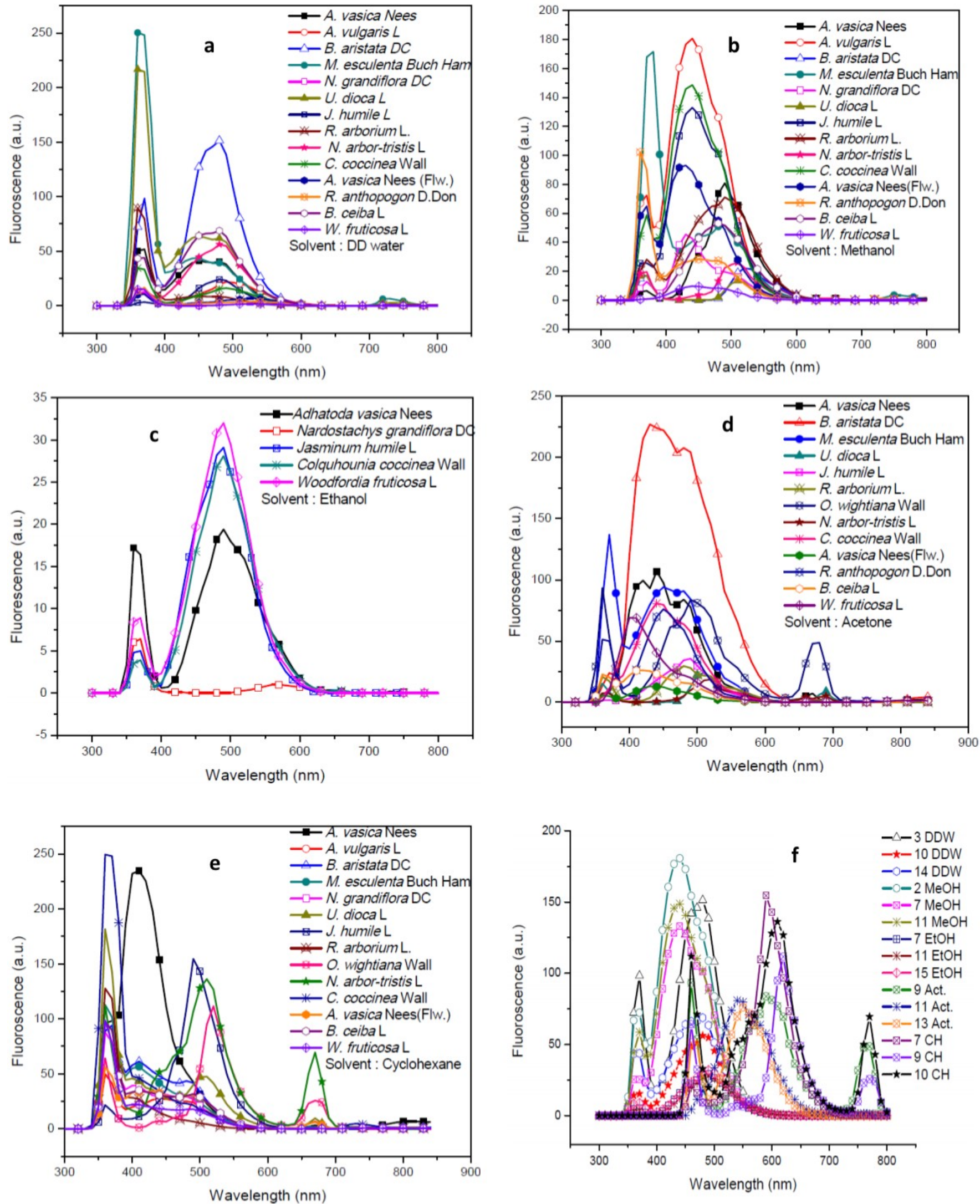

Figure 3 (a-e). Fluorescence spectra of various natural dye samples in different solvents as medium in the range of $300-800 \mathrm{~nm}$ wavelengths. Figure 3 (f) shows the best fluorescence spectra for some selective natural dyes in different solvents 
$\mathrm{MeOH}$ ), U. dioica L (in EtOH, Act, DCM and $\mathrm{CH}$ ), A. vasica Nees (in act), C. coccinea Wall (in DCM) and $O$. wightiana Wall, $A$. vasica Nees (Flow., in $\mathrm{CH}$ ) was found to exhibit better absorption in the UV-Vis spectrum of electromagnetic radiation. Remaining natural dye samples showed a monotonic decrease in the absorption for all the solvents studied, from wavelength

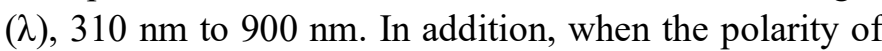
the solvent increases, blue shift in the major peaks of each absorbance spectrum was noticed (Figure 2, a-f). This may be due to the effect of polarity of the solvent (as expected) or it may be due to the extraction of different molecule(s) with unique absorbance which was absent in that particular solvent.

The absorption maxima for dye extracts in the wavelength range ca. $400-500 \mathrm{~nm}$ may be attributed to absorption due to xanthophyll, flavone, carotene, and rhein molecules, respectively (Zhou et al., 2011). Absorbance maxima observed at wavelength $\lambda=411 \mathrm{~nm}$ and $\lambda=665 \mathrm{~nm}$ (in cyclohexane) indicates the presence of either chlorophyll, anthocyanin or carotene or mixture of these compounds in the extract (i.e. these peaks may be due to absorption by individual species or may be attributed to the superposition of absorption peaks) since the natural dye generally contains either anthocyanin, chlorophyll carotenoids or mixture of them which have absorption peak at wavelengths $420 \mathrm{~nm}$ and $560 \mathrm{~nm}$ (Sari and Sunardi, 2011).

\subsection{Fluorescence of plant extracts (natural dyes)}

Figure 3 demonstrates fluorescence spectra, after excitation with $340 \mathrm{~nm}$, as a function of emitted radiation wavelength for all the 15 natural dye extracts in various solvents. Fluorescence spectra indicated that emission heavily depends on the solvent, just as absorbance did. Almost all of the natural dyes extract exhibited fluorescence spectra at the excitation wavelengths of ca. $400 \mathrm{~nm}$ (onset) - $650 \mathrm{~nm}$ (offset) and the emission wavelengths of $640 \mathrm{~nm}-700 \mathrm{~nm}$, except for few dyes. It was very interesting to note that for a particular sample in the same solvent, fluorescent maxima with respect to absorbance maxima shifted by about $25 \mathrm{~nm}$. For example, the absorbance maximum $(\lambda \max )$ of the dye sample $A$. vasica Nees that appeared at about $400 \mathrm{~nm}$ (see in Figure 2(a)), is found to occur at $425 \mathrm{~nm}$ in the fluorescence spectrum (see in Figure 3(a)).

Again, a careful observation of Figure 3 (a-e) indicated that when polarity of the solvent was increased, the major peak of the fluorescence spectrum shifted towards blue side: for instance, the fluorescence peak of sample $N$. arbor-tristis L. (in cyclohexane, see in Figure 3 (e)) that appeared at ca.525 $\mathrm{nm}$ found to occur at ca. $500 \mathrm{~nm}$ in distilled water (see in Figure 3(a)).
Also, the Figure 3(f) represents the fluorescence spectra of some of the selected dye samples which showed good absorbance and emission in the visible or in the near-IR region of the solar spectrum. The selective samples and solvents used are B. aristata DC, $N$. arbortristis L, B. ceiba L (in DDW); Artemisia vulgaris L, J. humile $\mathrm{L}$ (in $\mathrm{MeOH}$ ); $J$. humile $\mathrm{L}, C$. coccinea Wall, $W$. fruticosa $\mathrm{L}$ (in EtOH) and $N$. arbor-tristis $\mathrm{L}, R$. anthopogon D.Don (in $\mathrm{CH}$ ). Thus, the prevalence of emissions in broad wavelengths range in between 400 $\mathrm{nm}$ to $800 \mathrm{~nm}$ (except only a small window at about 725 $\mathrm{nm}$ ), of the natural dye samples may be useful for synthesizing organic light emitting diodes.

\subsection{IR spectroscopy of natural dye}

IR spectra recorded from natural dye samples; $A$. vasica, A. vulgaris, B. artista, $U$. dioica, J. humile, $R$. arborium, O. wightiana, $N$. arbortritis, $C$. coccinea, A. vasica flower and $R$. anthopogon, extracted in methanol, are presented in Figure $4(\mathrm{a}-\mathrm{c})$ along with probable functional groups present in each sample. All the samples analyzed showed broad peak around $3300 \mathrm{~cm}^{-1}$ which is characteristic of stretching vibration of $\mathrm{O}-\mathrm{H}$ bond. All three samples in Figure (4a) showed IR active in the peak positions at ca. $3326 \mathrm{~cm}^{-1}$ and ca. $2928 \mathrm{~cm}^{-1}$ which may be assigned to the bonded $-\mathrm{OH}$ and $\mathrm{C}-\mathrm{H}$ stretching modes, respectively. Also, A. vasica and $U$. dioica showed IR active in the peak position at ca.1628 $\mathrm{cm}^{-1}$, which may be assigned to the bonded $\mathrm{C}=\mathrm{O}$ stretching. Other probable functional groups are indicated in the figures themselves (see in Figure 4(b)). Similarly, J. humile, $R$. arborium, and $O$. wightiana showed IR active in the peak position at ca. $3301 \mathrm{~cm}^{-1}$ and $1607 \mathrm{~cm}^{-1}$ which may be assigned to the bonded $\mathrm{OH}$ group and bending $-\mathrm{NH}$ group, respectively. All the three samples presented in Figure 4(c); showed IR active in the peak positions at ca. $3357 \mathrm{~cm}^{-1}$ and $1028 \mathrm{~cm}^{-1}$ which may be assigned to the bonded $-\mathrm{OH}$ and ester $\mathrm{C}-\mathrm{O}$ modes, respectively.

\section{Conclusion}

From the UV-Vis-, fluorescence- and IRspectroscopic investigation of natural dyes, it was observed that all the 15 samples exhibited a broad absorbance peak from wavelength $\lambda$, ca. $300 \mathrm{~nm}$ (onset) - ca.500 nm (offset) and another additional sharp peak at $\sim 650 \mathrm{~nm}$ with FWHM of ca. $15 \mathrm{~nm}$. Moreover, among all the analyzed samples, $A$. vasica Nees, $N$. arbor-tristis L, $U$. dioica $\mathrm{L}, A$. vasica Nees, $C$. coccinea Wall and $O$. wightiana Wall, A. vasica Nees found to exhibit fairly better absorption both in terms of intensity and broader wavelength range in the visible spectrum. Also, major peaks in absorbance spectrum shifted towards blue side 


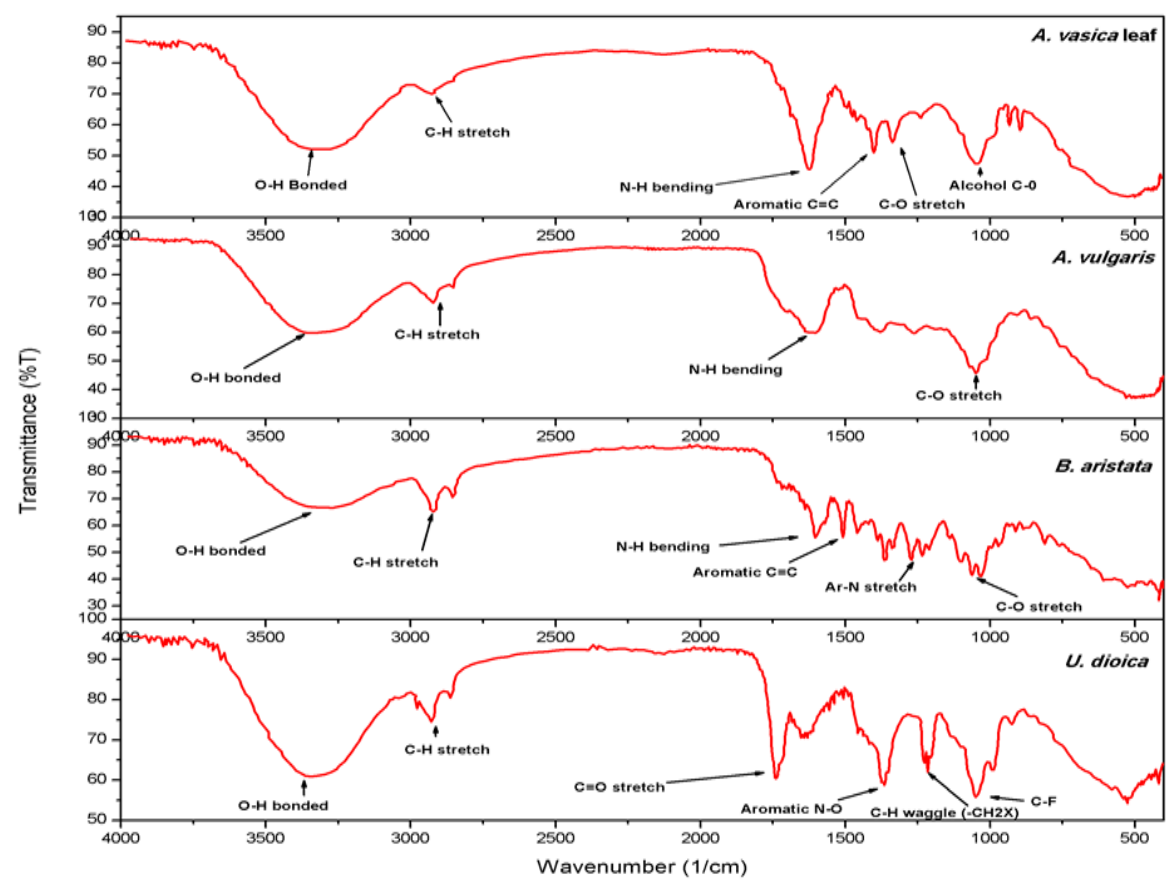

Figure 4(a). IR spectra recorded from natural dye samples; A. vasica, A. vulgaris, B. artista and U. dioica extracted in methanol. All the three samples showed IR active in the peak positions at ca. $3326 \mathrm{~cm}^{-1}$ and $2928 \mathrm{~cm}^{-1}$ which may be assigned to the bonded $-\mathrm{OH}$ and $\mathrm{C}-\mathrm{H}$ stretching modes, respectively. Also, $U$. dioica and A. vasica showed IR active in the peak position at ca. $1628 \mathrm{~cm}^{-1}$, which may be assigned to the bonded $\mathrm{C}=\mathrm{O}$ stretching. Other probable functional groups are shown in the figure itself.

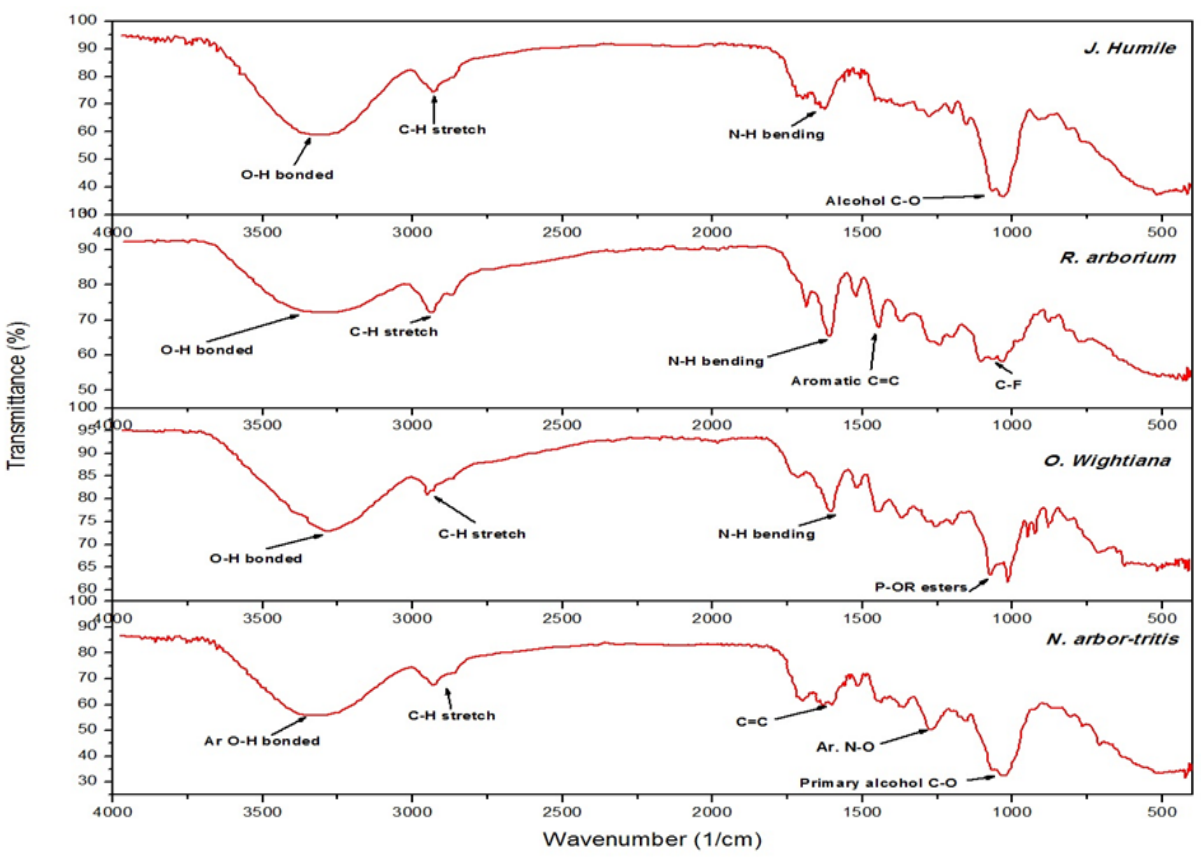

Figure 4 (b). IR spectra recorded from natural dye samples; J. humile, $R$. arborium, $O$. wightiana and $N$. arbortritis extracted in methanol. All the four samples showed IR active in the peak positions at ca. $2933 \mathrm{~cm}^{-1}$ which may be assigned to the C-H stretching modes. Similarly, J. humile, R. arborium and O. wightiana showed IR active in the peak position at ca. $3301 \mathrm{~cm}^{-1}$ and $1607 \mathrm{~cm}^{-1}$ which may be assigned to the bonded $-\mathrm{OH}$ group and bending $-\mathrm{NH}$ group respectively. Other probable functional groups are shown in the figure itself. 


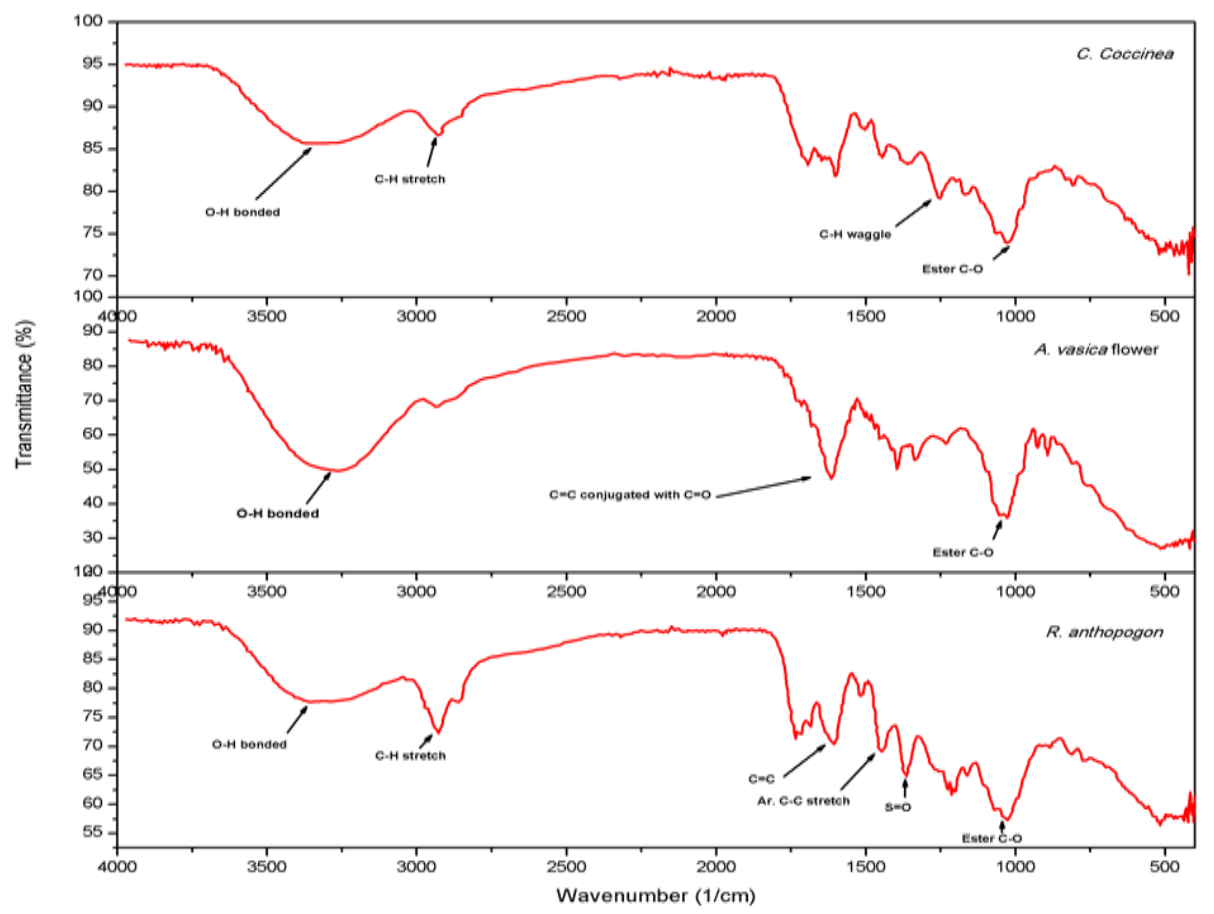

Figure 4 (c). IR spectra recorded from natural dye samples; $C$. coccinea, A. vasica flower and $R$. anthopogon extracted in methanol. All the three samples showed IR active in the peak positions at ca. $3357 \mathrm{~cm}^{-1}$ and $1028 \mathrm{~cm}^{-1}$ which may be assigned to the bonded $-\mathrm{OH}$ and ester $\mathrm{C}-\mathrm{O}$ modes, respectively. Also, A. vasica flower and $R$. anthopogon showed IR active in the peak position at ca. $2929 \mathrm{~cm}^{-1}$, which may be assigned to the $-\mathrm{CH}$ stretching. Other probable functional groups are shown in the figure itself.

when the polarity of the solvent increased. This may be due to the effect of the polarity of the solvent or it may be due to the extraction of different molecule (s) with unique absorbance which was (were) absent in a particular solvent.

Absorbance peak observed at wavelength $\lambda=411$ $\mathrm{nm}$ and $\lambda=665 \mathrm{~nm}$ (in cyclohexane) indicated the presence of either chlorophyll, anthocyanin or carotene or mixture of these compounds in the extract. These peaks may due to absorption by individual species or the resulting peaks may be attributed to the superposition of the individual absorption peaks. Since the natural dye generally contains either anthocyanin, chlorophyll carotenoids or mixture of them which have absorption peaks at wavelengths $420 \mathrm{~nm}$ and $560 \mathrm{~nm}$, exact identification of contributing species was not possible in our analysis of crude extract.

In summary, the prevalence of both the absorption and emissions in broad wavelength range from $400 \mathrm{~nm}$ to $800 \mathrm{~nm}$ (except only a small window at about 725 $\mathrm{nm}$ ), by some selective samples, particularly by $B$. aristata $\mathrm{DC}, N$. arbor-tristis $\mathrm{L}, B$. ceiba $\mathrm{L} ; A$. vulgaris $\mathrm{L}$, $J$. humile L; C. coccinea Wall, $W$. fruticosa $\mathrm{L}$ and $N$. arbor-tristis L, $R$. anthopogon D.Don, indicated that these samples may be useful for synthesizing OLEDs.

\section{Acknowledgments}

The authors gratefully acknowledge The World
Academy of Science (TWAS) for developing countries, Italy, for grant support.

\section{References}

Calogero, G., Di Marco, G., Cazzanti, S., Caramori, S., Argazzi, R., Di Carlo, A. and Bignozzi, C.A. (2010). Efficient dye-sensitized solar cells using red turnip and purple wild Sicilian prickly pear fruits. International Journal of Molecular Sciences, 11(1), 254-267. https://doi.org/10.3390/ ijms 11010254

Chang, H. and Lo, Y.J. (2010). Pomegranate leaves and mulberry fruit as natural sensitizers for dyesensitized solar cells. Solar Energy, 84(10), 18331837. https://doi.org/10.1016/j.solener.2010.07.009

Chang, H., Wu, H.M., Chen, T.L., Huang, K.D., Jwo, C.S. and Lo, Y.J. (2010). Dye-sensitized solar cell using natural dyes extracted from spinach and ipomoea. Journal of Alloys and Compounds, 495(2), 606-610.

https://doi.org/10.1016/ j.jallcom.2009.10.057

European Institute for Energy Research (2006). DyeSensitized vs. Thin Film Solar Cells. Retrieved from website: http://web.archive.org

Fernando, J.M.R.C. and Senadeera, G.K.R. (2008). Natural anthocyanins as photosensitizers for dyesensitized solar devices. Current Science, 95(5), 663666. 
Gao, F.G., Bard, A.J. and Kispert, L.D. (2000). Photocurrent generated on a carotenoid-sensitized $\mathrm{TiO}_{2}$ nanocrystalline mesoporous electrode. Journal of Photochemistry and Photobiology A: Chemistry, 130(1), 49-56. https://doi.org/10.1016/ S1010-6030(99)00193-8

Gokhale, S.B., Tatiya, A.U., Bakliwal, S.R. and Fursule, R.A. (2004). Natural dye yielding plants in India. Natural Product Radiance, 3(4), 228-234.

Grätzel, M. (2003). Review: Dye Sensitized Solar Cell. Journal of Photochemistry and Photobiology C: Photochemistry Reviews, 4(2), 145-153. https:// doi.org/10.1016/S1389-5567(03)00026-1

Hao, S., Wu, J., Huang, Y. and Lin, J. (2006). Natural dyes as photosensitizers for dye-sensitized solar cell. Solar Energy, 80(2), 209-214. https:// doi.org/10.1016/j.solener.2005.05.009

Nazeeruddin, M.K., De Angelis, F., Fantacci, S., Selloni, A., Viscardi, G., Liska, P. and Grätzel, M. (2005). Combined experimental and DFT-TDDFT computational study of photoelectrochemical cell ruthenium sensitizers. Journal of the American Chemical Society, 127(48), 16835-16847. https:// doi.org/10.1021/ja0524671

O'Regan, B. and Gratzel, M. (1991). A low-cost, highefficiency solar cell based on dyesensitized. Nature, 353(6346), 737-740. https:// doi.org/10.1038/353737a0

Qin, Y. and Peng, Q. (2012). Ruthenium sensitizers and their applications in dye-sensitized solar cells. International Journal of Photoenergy, 1-21. https://doi.org/10.1155/2012/291579

Sari, K. and Sunardi (2011). Characterization of Optical Properties of the Sansevieria trifasciata Extract as Dye Sensitized Solar Cells (DSSC). International Journal of Basic and Applied Sciences, 11(4), 10-13

Sirimanne, P.M., Senevirathna, M.K.I., Premalal, E.V.A., Pitigala, P.K.D.D.P., Sivakumar, V. and Tennakone, K. (2006). Utilization of natural pigment extracted from pomegranate fruits as sensitizer in solid-state solar cells. Journal of Photochemistry and Photobiology A: Chemistry, 177(2), 324-327. https:// doi.org/10.1016/j.jphotochem.2005.07.003

Susanti, D., Nafi, M., Purwaningsih, H., Fajarin, R. and Kusuma, G.E. (2014). The preparation of dye sensitized solar cell (DSSC) from $\mathrm{TiO}_{2}$ and tamarillo extract. Procedia Chemistry, 9, 3-10. https:// doi.org/10.1016/j.proche.2014.05.002

Zhou, H., Wu, L., Gao, Y. and Ma, T. (2011). Dyesensitized solar cells using 20 natural dyes as sensitizers. Journal of Photochemistry and Photobiology A: Chemistry, 219(2), 188-194. https:// 